\title{
CAPITAL STRUCTURE OF FOREIGN AFFILIATES AND THE INVESTMENT DECISION: TWO QUESTIONS TO CONSIDER
}

\author{
Fernando Merino \\ Faculty of Economics and Business Studies, Campus del Espinardo, \\ University of Murcia, 30100 Murcia, Spain \\ E-mail:fmerino@um.es \\ Received 29 November 2011; accepted 02 May 2012
}

\begin{abstract}
This paper analyses the ownership structure of foreign affiliates of Spanish firms. In contrast to previous studies on the participation degree, the paper highlights the importance of the previous decision to invest abroad. To do so, an econometric model with a limited dependent variable helps to show that to ignore the previous decision modifies the conclusions of the empirical analyses that raise an empirical model over a sample of firms with foreign affiliates. Additionally, the paper analyses in detail the importance of the cultural and political-legal differences between home and host countries that justify a different type of participation in equity of foreign affiliates. A clear implication for future research in this field is the need to reconsider the econometric approach to include the investment decision. As the paper has shown, a double-hurdle model provides notably different results than the usual approaches, which in this case are closer to the theoretical literature insights.
\end{abstract}

Keywords: firm's internationalization, foreign affiliates, multinational firms, wholly owned subsidiary, joint venture, equity structure, double-hurdle models, socio-cultural factors, Spain

Reference to this paper should be made as follows: Merino, F. 2013. Capital structure of foreign affiliates and the investment decision: two questions to consider, Journal of Business Economics and Management 14(Supplement 1): S470-S492.

JEL Classification: F23, G32, F21, D23, L24.

\section{Introduction}

The choice of the mode of entry is one of the topics in International Business that has merited many theoretical and empirical studies recently. In this area, the ownership structure and, specifically, the ownership that the parent firm holds is an important research topic, since it has consequences for both the investor firm and the subsidiary. This paper contributes to this research area by highlighting the importance that the (previous) decision to enter into a new market has in order to gain accurate conclusions from empirical analyses of the participation in equity of foreign subsidiaries. The second contribution of the paper is to show the importance of some of the host-country characteristics to the Spanish multinational ownership degree of their foreign affiliates.

At least two reasons have stimulated research into the mode of entry: the consequences for the firm and effects on the host country. The mode of entry is an important question 
for the investing firm, given that - as different papers remark - the ownership structure affects firms' performance (Chang et al. 2013; Rasheed 2005; Brouthers et al. 2003; Siripaisalpipat, Hoshino 2000), business opportunities for local firms (Prashantham, Birkinshaw 2008; Akande et al. 2010; Miozzo et al. 2012), the rest of the financial structure (Schindler, Schjelderup 2012), the knowledge of the local foreign market (Park et al. 2012), and even the probability of failure of the project (Hennart, Zeng 2002). Therefore, it is not surprising that normative consequences may emerge from this research topic in order to know ex-ante the optimal mode of entry. Additionally, as results for some of those topics are not conclusive (see Brouthers, Hennart 2007 or Yan Zeng 1999 for large surveys), research continues in order to discover which factors increase the probability of success.

Concerning the matters of interest for the host country, it must be noted that many countries impose restrictions on the equity share hold by non-residents. These limitations could condition the whole FDI project on the basis of different arguments (see, for example, OECD, "Product Market Regulation for OECD countries", on the OECD website). Better knowledge of the rationale behind the multinational firm's (MNE) strategy concerning the equity share in their foreign affiliates will shed light on the reasons why MNEs are willing to accept local participation in one country but not in others, and will then help to design policy reforms. Furthermore, the participation that a multinational firm may have in its subsidiary affects the spillovers that such presence generates in the host country's firms (Javorcik 2004) and even the productivity gap between foreignowned firms and home-owned firms in some countries (Dimelis, Louri 2002; Javorcik, Spatereaunu 2008). With this in mind, research on the explanatory factors in the mode of entry helps to know ex ante the effects of the multinational firms' presence.

As indicated previously, one of this paper's main contributions to the existing literature is its indication of the need to consider the decision about having an affiliate in empirical analyses of the mode of entry in order to have accurate results. Although econometric models have dealt with this kind of question for a long time, empirical papers on the mode of entry topic do not take into account previous decisions about the international involvement (see the surveys in Canabal and White (2008), Brouthers and Hennart (2007). Papers about foreign direct investments, as well as econometric literature, tend to distinguish between two key choices for analysing investing firms: 1) whether or not to invest abroad; and 2) whether or not to retain full ownership (and bear the full risk of failure) of such investment. The paper analyzes the factors that may explain each of these decisions and model the impact of each choice on the other, using the standard procedure in the econometric literature for this kind of data: a two-state Heckman model (Maddala 1983). As is the case in a large amount of the previous literature, Transaction Cost Economics provides the theoretical framework for this paper (with Teece (1986), and Anderson and Gatignon (1986), as seminal papers and Zhao, Luo and Suh (2004), and Canabal and White (2008) for meta-analytical reviews of the literature). It justifies the participation degree of an affiliate in the balance between the control that the parent company desires to hold and the possibility of incorporating the capabilities and/ 
or resources of the partner. The sources of these are uncertainty, the specificity of the involved assets and the frequency of the relationship.

The second contribution lies in how the country's characteristics affect participation in equity. This is done from a double perspective. On the one hand, the analysis is developed over a sample of subsidiaries of Spanish firms. Inasmuch as most of the literature is concentrated in countries such as the US, UK or Japan (see the meta-analysis in Tihany et al. (2005) and Zhao et al. (2004)), these results will help to build additional evidence for a country which is notably different from those previously mentioned, where firms have only recently incorporated international investing outflows. On the other hand, a detailed analysis of the characteristics of the host country is developed in order to highlight which of them are relevant to the participation decision. These elements are linked to the uncertainty supposed by external markets (see Ahsan, Musteen, 2011 or Morschett et al. 2010 for a review), so the rationale for its consideration fits with Transaction Costs Economics too. Notwithstanding this, the existing evidence is mixed and the need for research covering a wider set of countries is recognised. As previously noted (Brouthers, Hennart 2007; Dow, Karutnaratna 2006; Shenkar 2001; Tihanyi, Griffith, Russell 2005, etc.), one of the reasons for this could be the employed measures' inadequacy to capture the relevant underlying factors. The results of this paper will contribute to filling this gap.

The paper is organised as follows. The next section summarises the main aspects that theoretical models have indicated as explanatory of FDI at firm level, as well as the participation degree in foreign subsidiaries. Section 2 discusses the econometric model and its results. The last section summarises the conclusions.

\section{Equity structure in FDI projects}

\subsection{The investing abroad decision}

The decision of whether or not to engage in foreign direct investment is one of the main topics in the field of research into firms' internationalisation. Literature on FDI based on firm behaviour has paid attention to different aspects. Probably the most fruitful model has been the well-known eclectic paradigm of firms' internationalisation postulated by Dunning (1979). This establishes that a firm will internationalise its activities if it has some valuable assets (ownership advantage) and that such assets are more efficiently governed within the firm than by selling them in an open market (internalisation advantage). The third element of this paradigm (location advantage) acknowledges that assets and resources may vary in value from one country to another (due to factors such as transportation costs, market size, availability of raw materials or primary inputs) and as such does not contradict, but rather complements the basic model. Consequently, Dunning's (1979) eclectic paradigm is the keystone of a large set of empirical literature that evaluates the different factors highlighting the ownership, location and internalisation advantages of internationalisation. Other models (such as Hymer, the internationalisation-by-stages of the Uppsala School, the product cycle, etc.) do not contradict this wide framework; many of their postulates can fit into it. 
It must be noted that those firms which own any kind of profit-generating assets could exploit them in many different ways by establishing new plants abroad (from exporting output to granting third agents licences for the elements that generate advantage and obtain royalties). In this, the factors that justify internalisation advantages (in Dunning's paradigm terminology) become the key element in explaining firms' internationalisation.

The core idea of Dunning's eclectic paradigm is reinforced by the conclusions of Transaction Cost Economics (TCE hereafter; Williamson 1975, 1985) and the Organisational Capabilities Approach. TCE establishes that the election between internal provision and arms-length contracts will be based in the specificity of the involved assets and the inherent uncertainty of the project. That specificity is the source of the many of the advantages that configure the Dunning's model. On its part, the Organizational Capabilities concludes that the more specific are the involved assets in the internationalisation project, the more needed will be to retain control over those activities. Again, many of the elements that generate those specificities (susceptible of being eroded in different environment) are the sources of the advantages of the Dunning's model.

\subsection{The participation in foreign affiliates}

Once the would-be entrant has decided to exploit its assets/knowledge/advantages directly instead of exporting or licensing (or any other possibility which does not suppose FDI), another question arises: that is, the institutional arrangement about the foreign facilities. Note that these two decisions do not need to be considered sequentially; they can be simultaneous, and a decision to not hold any participation in a foreign firm will imply the no-investing option. The firm faces these two questions and the existing literature has shown that they have different determinants.

Transaction Costs Economics supports theoretically most of the literature on the mode of entry question, following the contributions of Anderson and Gatignon (1986), and Teece (1986) (see Brouthers, Hennart 2007, for a survey, and Zhao et al. 2004, and Canabal, White (2008) for meta-analytical reviews of the literature). Basically, it states that the optimal governance form is the one that minimises the sum of transaction costs. As the costs of adaptation, performance monitoring and safeguarding against opportunistic behaviour increase, the firm will prefer to retain a higher degree of control, and therefore will choose to keep the entire ownership or at least the majority of participation. Thus, the nature of the involved assets becomes determinant: the more specific those assets are, the larger are the adaptation, bargaining and monitoring costs (i.e. transaction costs); then control becomes the optimal solution. Partial participation of local partners may become a way to add to those resources that local agents may be able to provide more cheaply (typical examples include knowledge of local market, contact and bargaining power with local suppliers/government officials/trade unions, knowledge of formal or informal procedures, etc.) to the advantages that the foreign investor may hold. Obviously, the availability of local resources that add value to the resources and capabilities carried out by the foreign investor, and how cheaply a local agent can obtain them, condition the optimality of joint ventures between the investor and local partners. 
Uncertainty surrounding a transaction will influence the entry mode choice too. Uncertainty generated by the difficulty of controlling the partner's activities (knowledge leakages, marketing efforts, and so on) will move the parent firm to maintain a high degree of control over the foreign affiliate (Williamson 1991). However, it must be noted that partial participation on equity is a way to share risk with local agents. To the extent that local agents have a more complete knowledge of the host country conditions, their participation will reduce some of the risks of overseas investments. The larger their participation, the larger the risk reduction is (out of moral hazard problems).

Parent firms' size will be correlated with the invested amount and then with the equity share that they hold. Smaller firms face a relatively higher risk, given that some fixed costs and minimum investment requirements exist in FDI. In this case, smaller firms are expected to present smaller participation in their foreign affiliates' equity. Besides, imperfect capital markets mean that smaller firms have fewer resources to invest (Fazzari et al. 1988). However, as Sanna-Randacio (1991) point out, very large firms may exert more power in relationships with other partners and, then, may be able to monitor and influence the activities of their affiliates with lower levels of participation. So, we may conclude that a direct relationship could be expected for smaller parent firms, while for large firms this relationship could be milder.

The size of the participating firm will affect the chosen ownership structure too. There are two main reasons for this relationship, although they are contrary to each other. Those firms which invest abroad as a strategy of 'following the leader' (as Knickerbocker (1973) establishes in some oligopolistic markets) will prefer to share those facilities with another partner. In this case, the firm's objective is to be present in that market to avoid the competitor monopolising it, ensuring that it remains a base for future growth. On the opposite side, it may be argued that size is a proxy of market power, so the parent firm will choose a larger equity share in order to extract those rents. Additionally, as Nakamura and Yeung (1994) have suggested, the affiliate's size may affect the amount of assets that the parent firm will transfer, reinforcing the positive relationship between affiliate size and participation in equity.

\subsubsection{The role of the host country}

The literature on the mode of entry decision reinforces the need to study some characteristics linked to country factors (see the seminal papers of Kogut, Singh 1988; Gatignon, Anderson 1988; Erramili 1996) and a large part of this literature has included different constructs in order to evaluate their influence (see large surveys in Canabal, White 2008; Ahsan, Musteen 2011). There are many factors that fit into this consideration, such as national culture distance, sociological issues, legal framework, etc.

The rationale of its consideration is based on the perception that differences between home and host countries is a source of uncertainty in the TCE framework. These countries' differences (in its widest meaning) or psychic distance require specific management of relationships with clients, employees, suppliers, local authorities, etc., and the need to consider factors that may affect acceptance of the output, etc. The larger the 
country differences are, the more costly becomes the incorporation and handling of that knowledge. Local partners are a way to dispose of country-specific management; from this point of view, their participation should go hand-in-hand with psychic distance, reinforcing the effect of the uncertainty of a less well known business environment. However, cultural distance may increase the costs of communication, monitoring, transmission of goals, etc. with local partners as well as the perceived risk by foreign investors (Yamin, Golesorkhi 2010). In this case, it can also be viewed as an opposite relationship: as country differences increase, the incorporation of local partners is expected to reduce (for example Hennart and Zeng (2002), conclude that cross-cultural differences between partners reduce the longevity of foreign subsidiaries in the US, Jiang et al. 2011 do the same for subsidiaries in China). Summing up, TCE can justify opposite views of the relationship between countries' differences and the participation of foreign affiliates. In fact, there is empirical evidence in favour of both a direct relationship (Anand, Delios 1997; Bowe et al. 2013), an inverse one (Kogut, Singh 1988), and a lack of significance (Demirbag et al. 2009; Gatignon, Anderson 1988). Tihanyi et al. (2005) meta-analysis of 67 research articles concludes that the relationship between cultural distance and mode of entry is statistically non-significant unless US-based firms are involved, when the opposite is true. It can therefore be stated that this is an open theme for research where the intrinsic difficulty in measurement joins the huge casuistic that may justify the differences observed in the literature (as Brouthers, K. D. and Brouthers, L. E. (2001) point out) or even the reinforcing effects of some of the dimensions that generate the country differences over other ones (as López-Duarte and Vidal-Suárez (2013) show between cultural distance and political risk).

Beyond the psychic distance among countries, differences in their political-legal systems are important in the participation decisions of affiliates. It must be noted that their relevance is not due to their consequences for the investment project's profitability (with regard to, for example, labour laws or tax codes) but because they can affect optimal participation on equity. Firstly, we may remark on the role of protection to the rights of firms' shareholders and debtors. Stronger protection for shareholders will suppose a less risky environment and, then, will provide a friendlier framework for participation on equity. Conversely, higher protection of the rights of debtors supposes a weaker position for shareholders (disregarding any questions of fairness) that may place conditions on the participation of a shareholder in an affiliate. Additionally, as one investor shares equity with other partners, the necessity of having a true and fair image of the subsidiary increases. So, if the regulations about accounting and auditing enforce a fair and true image of the firm, foreign investors will be less reluctant to admit other investors.

However, we cannot forget that some factors which go beyond the characteristics of the firm may govern decisions on establishing production facilities (and the choice of the optimal ownership structure), such as the existence of legal restrictions (as it happen in some industries in Cuba or China) or the existence of hysteresis in the investment decision. 


\section{Empirical analysis}

\subsection{The database}

Empirical analysis of the ownership structure in firms' foreign direct investment projects must take into consideration that this is a recent phenomenon for Spanish manufacturers. This fact suggests that foreign subsidiaries are more recent and more strongly influenced by the new global framework (where international investment flows have experienced an important deregulation). Globalisation supposes that for many firms, exploiting advantages in different countries and serving an international market is their natural business environment, so competition becomes another stimulus for firms' internationalisation. In any case, it must be noted that Spain has received less attention than other countries which are home to those firms whose mode of entry has been analysed (see Canabal and White (2008)).

The data used to study the relationship between parent firms and their manufacturing affiliates in this paper are provided by the Survey on Business Strategies (Encuesta Sobre Estrategias Empresariales, ESEE). This survey is carried out by the Spanish Ministry of Industry covering a panel of about 2,000 Spanish manufacturers. As only a fraction of them have affiliates abroad, it is an adequate datasource to implement the proposed econometric approach that combines the investment decision and the degree of participation on foreign affiliates equity.

\subsection{Some descriptive data of foreign affiliates of Spanish manufacturing firms}

Since the Spanish case is less well known than others which have been more deeply studied in the mode of entry literature, this subsection presents some descriptive data regarding Spanish multinationals and their affiliates abroad. Given that more information can be found from complementary sources (see for example Delgado-Gómez et al. (2004), Galán and González-Benito (2006)), the presented information originates from ESEE. Owned firms located abroad dedicated uniquely to trading activities are not considered here, since participation on its equity will depend on the need to control the marketing activity abroad instead of the protection of the whole set of specific assets the parent firm transfers when it produces abroad (for an analysis of trading subsidiaries see Merino and Salas (2002)). The database contains information on the number of subsidiaries with productive activities abroad. Beyond the total number of firms, the information collected distinguishes the number in four different regions in the world (EU as a whole, OECD countries with the exception of Mexico, Latin American countries, and others).

The first, remarkable result observed in Table 1 is the fact that ownership of foreign (production) subsidiaries is relatively more common among large Spanish firms than among small ones, as expected. These results also show that while among small firms the greatest percentage of those with foreign subsidiaries is found in the machinery industries, among large ones the firms in these industries are the ones with the smallest percentage. Then, the results raise the need to pay attention to a firm's size, not only because the proper investment decision, but also for the relevance of some of the explanatory factors. 
Table 1. Affiliates of Spanish manufacturing firms

\begin{tabular}{|c|c|c|c|c|c|c|c|c|c|c|}
\hline & \multicolumn{5}{|c|}{ Small-medium firms (<200 employees) } & \multicolumn{5}{|c|}{ Large firms (>200 employees) } \\
\hline & 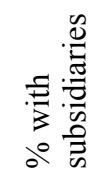 & ?고 & 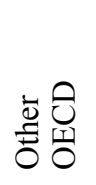 & 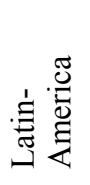 & 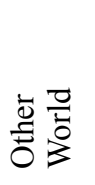 & 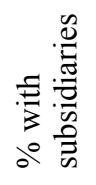 & ?모 & 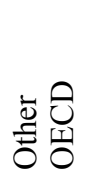 & 占鸪 & 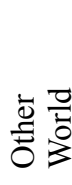 \\
\hline TOTAL & 3.3 & 65.9 & 7.3 & 26.8 & 9.8 & 28.5 & 70.5 & 29.0 & 44.3 & 22.2 \\
\hline Consumption goods & 2.2 & 75.0 & 12.5 & 12.5 & 12.5 & 27.3 & 71.4 & 42.9 & 45.7 & 34.3 \\
\hline Intermediate goods & 2.9 & 57.9 & 5.3 & 31.6 & 10.5 & 31.9 & 72.0 & 23.0 & 43.0 & 19.0 \\
\hline Machinery & 5.7 & 71.4 & 7.1 & 28.6 & 7.1 & 23.3 & 65.9 & 31.7 & 46.3 & 19.5 \\
\hline
\end{tabular}

Source: Own elaboration on ESEE.

The second result we can see in Table 1 is that the European Union is the main destination for these foreign investment projects. Among small firms, the importance of this region is even greater. This result may suggest that political stability, a better known legal and institutional framework and exchange-rate stability play a key role in Spanish manufacturing firms' decisions to invest abroad. The second most important destination is the Latin American region. It is well known that Latin America became the main destination for Spanish FDI outflows in the 1990s. The most remarkable (and best known) cases are those of financial firms, public utilities and oil firms. These data show that for manufacturing firms, Latin America has become an important destination for FDI outflows.

As well as this data, which refers to the entire set of foreign subsidiaries (more than 700), the dataset contains additional information on the main subsidiary owned by each firm. As is well known, determination of the criteria to establish which is the main subsidiary is open to general discussion (while some argue in favour of size, measured in number of employees or in shipments, firm's assets, etc., others argue in favour of the relevance of the subsidiary in terms of profit generated or its links with the production chain of the parent firm or strategic considerations). The questionnaire used offered no suggestions to the surveyed (parent) firm about which criteria should be followed in order to gain information about the subsidiary that the parent firm considers most important to its entire business. Consequently, the results will make reference to the relationship with the main subsidiary (subjectively determined by the parent firm), not all of them. From the 168 identified subsidiaries, Table 2 presents some descriptive data on the frequency of cases where the participation is over $50 \%$; that is, cases where the parent firm holds indubitable control over the subsidiary.

The results in Table 2 show that majority participation is the most common case among subsidiaries of Spanish manufacturing firms. It suggests that these firms may have more specific assets that need to be protected and that increase transaction costs, or that small firms face tighter financial restrictions in investing the same amount of resources in a single project. Besides, majority participation among industries between large and small 
Table 2. Percentage of firms with majority position on their main subsidiary abroad

\begin{tabular}{lcc}
\hline & Small-medium firms $(<200$ employees $)$ & Large firms $(>200$ employees $)$ \\
\hline TOTAL & 56.1 & 77.8 \\
\hline Consumption goods & 50.0 & 85.7 \\
\hline Intermediate goods & 57.9 & 81.0 \\
\hline Machinery & 57.1 & 63.4 \\
\hline
\end{tabular}

Source: Own elaboration on ESEE.

firms. While differs among small firms, industries of consumption goods present the lowest percentage of majority participation in their affiliates; among large firms this sector has the highest percentage. This result could be justified by the different strategies possibly applied by these firms: while small firms try to compete on costs without creating specific assets, meaning there is no need to hold a large participation in affiliated firms, it is more common for large firms to compete by creating specific assets, which require larger participation.

\subsection{Econometric analysis}

As indicated in the introduction, this paper studies participation in the foreign subsidiaries of manufacturers on the basis of the theoretical framework referred to in section 2 that is, the traditional explanatory factors used to analyse this topic. Foreign subsidiaries are not inherent to a firm; their existence is the result of a decision taken by the firm. But, the usual methodology on the empirical analyses does not consider this fact. As Canabal and White (2008) show, the statistical methodology in the large set of papers they analysed departs from the fact that the firm has decided to become international. Then, these papers employ econometric models to explain the participation of the parent firm once the firm has taken such a decision.

But the fact that one firm has to face a previous (in the conceptual meaning, not necessarily in the chronological one) decision requires a reconsideration of those econometric models. The econometric literature has established (Maddala 1983: chapter 8) that to avoid biased results in the study of the participation degree of a foreign affiliate, the econometric model must consider the previous decisions about its existence. Otherwise, a problem known as 'sample selection bias' will affect the econometric estimators. Different models may be used to handle this; according to assumptions on the explanatory variables for the two decisions (whether they are the same, have the same effects, etc.). In this paper the Heckman procedure is used to correct this sample selection bias, since it imposes neither the same set of explanatory variables nor the same effects or assumptions on the unobservable terms. The Heckman model requires an estimation of the decision of whether the observation is included in the sample or not (i.e. whether the firm has an affiliate abroad). Through its results the Mills ratio is computed and its inclusion in the second stage of the econometric model (the participation degree in the foreign affiliate) allows for avoiding the bias that the estimators will otherwise present. 


\subsubsection{Affiliates abroad}

The Heckman econometric model requires the estimation of a model for the existence of foreign affiliates in order to get the Mills ratio that will be introduced in the estimation for the equity structure. To do this, an econometric model following the well established results of the literature has been implemented and estimated. The set of covariates for this model has been selected on the basis of Dunning's eclectic paradigm, aiming to capture the assets and resources that the parent firm will transmit (directly or implicitly) to its affiliates. The intangible assets are measured by firms' efforts in R\&D as well as advertising. R\&D measures the parent firm's expenditure on R\&D normalised on the figure of total sales. ADV captures the advertisement expenditures, also normalised on total sales. The variable BRAND values 1 if the firm promotes its own brand, and zero otherwise. A firm's size is measured by the number (and its squared value) of employees.

Table 3 collects the estimates of the econometric model on the existence of foreign (production) affiliates of the firms in the sample. The results of this estimation confirm the existence of a positive relationship between firm size and the probability of holding participation in foreign firms. Although the coefficient of the squared value of size is negative (that is, an inverse U-shaped relationship), the values indicate that the relationship is direct until the workforce nears 7,250 employees, which supposes the great majority of the existing firms. This result indicates that there are some kind of specific assets linked to firm size that are transmitted to foreign facilities. It could also indicate that small firms face some kind of financial restriction that, ceteris paribus, will impede their investments abroad. This conclusion should be considered preliminary given the lack of

Table 3. Probit estimation on existence of foreign subsidiaries

\begin{tabular}{lcc}
\hline Constant & $\begin{array}{c}-1.536 \\
(-29.57)\end{array}$ & $* * *$ \\
\hline SIZE & $\begin{array}{l}0.844 \\
(8.51)\end{array}$ & $* * *$ \\
\hline \multirow{2}{*}{ IIZE $^{2}$} & $\begin{array}{l}-0.580 \\
(-6.06)\end{array}$ & $* * *$ \\
\hline R\&D & 0.383 & $* *$ \\
\hline ADV & $(2.84)$ & \\
\hline \multirow{2}{*}{ BRAND } & 0.0645 & $* * *$ \\
& $(4.76)$ & \\
\hline Number of observations & -0.0322 & \\
\hline Log. likelihood & $(-0.16)$ & \\
\hline Joint significance test & 1,447 & \\
\hline$\%$ of correct predictions & $87.6 \%$ & \\
\hline
\end{tabular}

Notes: $t$-ratios in parentheses; $* * *$ and $* * *$ indicate statistical significance at 10 and 5 and $1 \%$, respectively. 
data to measure the existence of financial restrictions. Besides the information on the characteristics of Spanish manufacturing firms with foreign affiliates, this estimation provides the inverse Mills ratio for the different models to estimate the participation degree.

Concerning specific assets, we observe a direct relationship between R\&D activities and investment abroad. This observed positive relationship is consistent with the traditional hypotheses of Dunning's eclectic paradigm. The specific assets linked to the advertisement effort show a significant effect. That is, the larger the reputation and recognition of the firm thanks to its expenditures in advertisement, the more likely it is to have facilities abroad. On the other hand, promotion dedicated specifically to a brand has no significant effect.

To sum up, the existence of production affiliates abroad among Spanish manufacturers seems to be related to the firm's size, and the more specific assets (in technology and marketing) a firm has, the more likely it is to have production affiliates abroad. These results can be considered in accordance with Dunning's eclectic paradigm as well as most of the empirical literature on this topic.

\subsubsection{Participation in affiliates abroad}

As discussed in section 1, the explanatory variables of the decision to invest abroad are not necessarily the same ones that explain the participation degree of those affiliates. From the theoretical framework we can identify a set of explanatory variables formed by those that capture the assets and resources the firm will transfer (the R\&D and advertisement expenditure, normalised on total sales, and the dummy variable BRAND). As in the model on the existence of affiliates, parent-firm size is considered in a quadratic shape. As Canabal and White (2008) show, size and R\&D intensity are among the most widely used variables in the literature on mode of entry.

In the estimation of the capital share owned by the parent firm, the relevant sample is, obviously, the subset of firms that own such. The econometric model includes some characteristics of the subsidiary too, since they can modify the effect of the rest of the variables. These characteristics are captured by a set of dummy variables that makes reference to whether it elaborates an output similar to that of the parent firm (SIMIL), whether it assembles or adapts the output of the (Spanish) parent firm (ADAPT) and whether it trades the output of the parent firm (TRADE). Note that they do not capture excluding alternatives, since a firm can be classified into more than one of these groups (as well as none of them). Size (measured by number of employees in thousands, which avoids bias from currency conversion) has also been included (AFFIL-SIZE).

The last set of variables to consider is that which aims to measure differences among countries. As it was discussed in section 1.2.1, those differences are not limited to the cultural dimension of the societies but should be extended to all those elements that may generate any kind of risk or costs in the interaction between the parent firm and its affiliates. However, the empirical analysis require to specify the sources of such differences in a way that can be measured. Basically, we can specify two dimensions to capture: political-legal differences on the one hand, and cultural distance between the origin country (Spain in this case) and the location of the affiliate on the other. 
A first alternative consists in the use of dummy variables. They will be included in the econometric model in order to capture country specific effects. This approach will provide a certain measurement of the distance between the home country (Spain in this case) and the one that each dummy considers. But it does not identify the nature of the difference which is relevant for the mode of entry, although in a second stage this distance could be proxied by relating the estimated values with different measures of distance between countries. However, this procedure requires sufficient cases of foreign affiliates in each of the observed countries, which unfortunately were not found in this sample. Obviously, countries can be grouped into regions and the effect under scrutiny will be captured to the extent that the grouping includes those countries with the same (relevant) similarities.

In this alternative, two sets of dummy variables have been included to capture these effects (see Annex A for details) in the econometric model. The first grouping is based on the political-legal framework (see Beck et al. 2001 for more details): French tradition, Anglo-Saxon tradition, German tradition, Arab, Latin American and others. The second grouping is based on the common division of economic blocks: EU, the rest of OECD (apart from Mexico), Latin America, and others. Another possible cluster is the one provided by the results of the GLOBE project (see Gupta et al. 2002). Given that it is focused on the cultural dimension, it seemed unnecessary to consider a third grouping as the use of indexes may capture this effect.

Another approach consists of including indexes that aim to measure these differences among countries as Yamin and Golesorkhi (2010) also do. The literature offers different approaches to this question, although most have important limitations: their values are outdated as time passes and societies evolve; they aim to capture numerically concepts which are not always measurable (such as political stability, economic systems, ownership protection, social, cultural, psychological values and attitudes, and so on); surveys are conditioned by the difficulty and costs inherent to a multinational study and consequently their samples are designed lacking the required representativeness, and so on. This aside, they are often used in the analysis of decisions in different countries, and some of them are calculated and published for large sets of countries. As they are not available for every country in which Spanish manufacturers have affiliated firms, the sample size will be reduced in the econometric estimations where they are considered. To gain maximum confidence, two sets of indexes have been considered (see Annex B for details).

First, to capture the political-legal frame, four variables have been included: protection of shareholders' rights (S-RIGHTS), of debtors (D-RIGHTS), reliability of accountancy rules (ACCOUNT) and political openness (POL-OPEN). Specifically, the investment becomes more risky the less protection is offered to shareholders, the more protection is offered to debtors or the less reliable accountancy is, so the parent firm will be less prone to invest resources. An additional variable has been included to capture the openness of the political system (associated with transparency), since in an open political system it will be less necessary for local partners to hold contacts and relationships with local authorities. 
Second, to capture the cultural distance between Spain and the other countries, the four indexes of Hofstede have been used (power distance, POWER; individualism, INDIVIDUAL; uncertainty avoidance, UNCERTAIN; and masculinity, MASCUL). The fifth dimension included in later studies (long-term orientation) has not been included, given that its inclusion would necessitate omitting several important countries from the analysis. The use of the four indexes, instead of a construct that synthesises them as some papers do, is justified by Dow and Karunaratna (2006), who conclude that these four indexes are orthogonal to explain trade flows; that is, their explanatory capability cannot be summarised in a single dimension. If this is also the case for the mode of entry option, a synthetic indicator will miss some of the effects that the differences in each of the four dimensions may have. Since the sample is large enough to generate degrees of freedom in the estimation with the four additional variables, this seems a more efficient use of the information available.

Obviously, some of the requirements that Shenkar (2001) establishes cannot be fully satisfied with the considered variables (such as the consideration of heterogeneity inside each country, or the cultural heterogeneity for each firm), and not even with the use of country dummies. Notwithstanding this, it seems plausible that differences between the home and host countries will be captured in a more precise form by a set of variables than with a construct based on the four (or five) dimensions of cultural differences raised by Hofstede.

Table 4 contains different estimated models on the mode of entry based on the participation of the Spanish parent firm in its main foreign affiliate. Obviously, the sample is formed only by firms which actually have foreign affiliates; this makes the sample significantly smaller than the whole ESEE database, although the number of observations is large enough to implement the estimation technique suggested to circumvent the limitations of the usual analyses of mode of entry models. Column I contains the model, taking into account the previous question about whether or not to have a subsidiary abroad, which requires inclusion of the inverse Mills ratio as econometric models of sample selection indicate. As discussed, this paper aims to show the need to consider the previous decision about investing abroad to get accurate estimations on a mode of entry model. So, Table 4 also contains the results of estimating different mode of entry models, following the usual methodology to analyse this topic (see the survey in Canabal and White (2008) and Morschett et al. (2010)). Specifically, it reports the results of estimating Probit models where the dependent variable values 1 for full participation (column II), over 90\% (column III) and over 50\% (column IV) are included.

First of all, we must conclude that there are important differences when using Heckman's procedure to avoid sample selection bias in the econometric estimation, even with the same data and variables. In the case of not considering the previous decisions (as the models in columns II-IV do), conclusions on the relevance of variables such as size or R\&D will differ notably.

The econometric results, once the effect of the sample selection has been considered (column I in Table 4), show some important conclusions for knowledge of the mode of entry. The estimated coefficient of parent-firm size shows an inverse U-shaped relationship. 
Table 4. Estimation of different models for the participation on equity of main subsidiary

\begin{tabular}{|c|c|c|c|c|c|c|c|}
\hline & I & & II & & III & & IV \\
\hline Estimation method & $\begin{array}{l}\text { OLS (White) } \\
2^{\text {nd }} \text { stage of } \\
\text { Heckmans } \\
\text { procedure }\end{array}$ & & Probit & & Probit & & Probit \\
\hline Dependent var. & $\begin{array}{c}\text { Participation } \\
(\%)\end{array}$ & & $\begin{array}{c}=1 \text { if part } \\
=100 \%, \\
0 \text { otherwise }\end{array}$ & & $\begin{array}{c}=1 \text { if part } \\
>90 \%, \\
0 \text { otherwise }\end{array}$ & & $\begin{array}{c}=1 \text { if part } \\
>50 \%, \\
0 \text { otherwise }\end{array}$ \\
\hline Constant & $\begin{array}{l}314.500 \\
(2.959)\end{array}$ & $* *$ & $\begin{array}{c}-0.222 \\
(-0.745)\end{array}$ & & $\begin{array}{c}-0.398 \\
(-1.302)\end{array}$ & & $\begin{array}{c}0.104 \\
(0.319)\end{array}$ \\
\hline SIZE & $\begin{array}{l}-60.500 \\
(-1.854)\end{array}$ & $*$ & $\begin{array}{c}0.468 \\
(2.114)\end{array}$ & $* *$ & $\begin{array}{c}0.653 \\
(2.586)\end{array}$ & $* *$ & $\begin{array}{c}0.523 \\
(1.862)\end{array}$ \\
\hline SIZE $^{2}$ & $\begin{array}{c}4.295 \\
(1.910)\end{array}$ & $*$ & $\begin{array}{c}-0.023 \\
(-1.152)\end{array}$ & & $\begin{array}{c}-0.038 \\
(-1.764)\end{array}$ & $*$ & $\begin{array}{c}-0.031 \\
(-1.348)\end{array}$ \\
\hline $\mathrm{R} \& \mathrm{D}$ & $\begin{array}{c}-4.394 \\
(-2.256)\end{array}$ & $* *$ & $\begin{array}{c}0.057 \\
(1.294)\end{array}$ & & $\begin{array}{c}0.020 \\
(0.424)\end{array}$ & & $\begin{array}{l}-0.015 \\
(-0.301)\end{array}$ \\
\hline $\mathrm{ADV}^{(1)}$ & $\begin{array}{c}-4.870 \\
(-1.891)\end{array}$ & $*$ & $\begin{array}{c}0.033 \\
(1.197)\end{array}$ & & $\begin{array}{c}0.082 \\
(2.237)\end{array}$ & $* *$ & $\begin{array}{c}0.066 \\
(1.581)\end{array}$ \\
\hline BRAND & $\begin{array}{l}18.520 \\
(3.827)\end{array}$ & $* * *$ & $\begin{array}{c}0.603 \\
(1.317)\end{array}$ & & $\begin{array}{c}0.920 \\
(1.539)\end{array}$ & & \\
\hline R. Mills & $\begin{array}{c}-129.400 \\
(-2.362)\end{array}$ & $* *$ & & & & & \\
\hline AFFIL-SIZE & $\begin{array}{l}-0.407 \\
(-0.095)\end{array}$ & & $\begin{array}{l}-0.159 \\
(-0.792)\end{array}$ & & $\begin{array}{l}-0.029 \\
(-0.108)\end{array}$ & & $\begin{array}{c}-0.162 \\
(-0.619)\end{array}$ \\
\hline SIMIL & $\begin{array}{l}-3.127 \\
(-0.453)\end{array}$ & & $\begin{array}{c}-0.571 \\
(-1.840)\end{array}$ & $*$ & $\begin{array}{c}-0.072 \\
(-0.235)\end{array}$ & & $\begin{array}{c}0.167 \\
(0.501)\end{array}$ \\
\hline TRADE & $\begin{array}{c}4.957 \\
(0.713)\end{array}$ & & $\begin{array}{c}-0.244 \\
(-0.774)\end{array}$ & & $\begin{array}{c}0.254 \\
(0.793)\end{array}$ & & $\begin{array}{c}0.387 \\
(1.103)\end{array}$ \\
\hline ADAPT & $\begin{array}{c}6.687 \\
(1.192)\end{array}$ & & $\begin{array}{c}0.136 \\
(0.511)\end{array}$ & & $\begin{array}{c}0.185 \\
(0.662)\end{array}$ & & $\begin{array}{c}0.372 \\
(1.164)\end{array}$ \\
\hline Number of obs. & 153 & & 153 & & 153 & & 153 \\
\hline $\mathrm{R}^{2}$ & 0.1692 & & & & & & \\
\hline Joint significance test & 2.892 & $* *$ & 15.19 & $*$ & 24.46 & $* *$ & 12.36 \\
\hline$\%$ correct predtions & & & $64.1 \%$ & & $73.2 \%$ & & $77.1 \%$ \\
\hline
\end{tabular}

Notes: $t$-ratios in parentheses; $* * *$ and $* * *$ indicate statistical significativity at 10,5 y $1 \%$ respectively; BRAND could not be included in IV because all cases were BRAND $=1$.

As in the probit estimation of Table 3, in the largest part of the observed rank the relationship is direct (the maximum is near 7,050 employees). Then, those assets linked to size (such as know-how or managerial skills) are transmitted to the subsidiary, and the firm retains control through larger participation in its subsidiary. At the same time, it cannot be denied that smaller firms face tougher financial restrictions which make it more difficult for them to have greater participation in their subsidiaries, other things 
being equal. Mutinelli and Piscitello (1998) also obtain an inverse U-shaped relationship for Italian firms, although this is through a probit model on full-ownership ( $>95 \%$ on equity) vs. joint venture without considering previous decisions.

Concerning the specific assets which the firm may generate by means of its expenditure on R\&D and advertising, we find a different effect when the sample selection has been considered (column I) than when just a binary model is estimated (columns II-IV). Mutinelli and Piscitello (1998) also obtain a negative sign, which they justify by noting Italy's weak innovation system and Italian firms' use of joint ventures as a means to incorporate technology and innovation results. Le Bas and Sierra (2002) observe than in Italy the technology seeking FDI strategy is common, as it does not happen in other advanced European economies. The same reasoning can be applied for Spanish firms, especially given that the Spanish effort on R\&D is even smaller than the Italian (according to EUROSTAT in Italy it reaches $1.04 \%$ of GDP while in Spain it is $0.94 \%$ ). Birkinshaw and Hood (2000) showed that subsidiaries in leading-edge industries require more autonomy and contact with a local network. To the extent that more R\&D-intensive firms transmit this characteristic to their subsidiaries, the need for participation in host country networks and closer contact with stakeholders can explain the smaller degree of ownership participation of the parent firm.

The results relating to marketing effort require more careful discussion. While advertisement expenditure shows a negative sign with a low statistical signification, an own brand shows a positive sign. On the basis of Transaction Costs Economics, a positive sign is expected, so the negative sign on ADV may be justified by the fact that the figure relates to total expenditure of the parent firm without including its affiliates.

The rest of the explanatory variables refer to some of the subsidiary's characteristics. As we can see, the participation of the parent firm has a negative relationship with its size, although it is not statistically significant at the usual thresholds. Some kind of financial restriction may be the reason why participation is not larger in bigger firms. It can be also explained by the need to be present in foreign markets to 'follow the leader' in each market, with minority participation enough to accomplish this target for many firms.

Finally, the variables that capture the activities of the subsidiary firm do not show any significant coefficient. That is, whether they trade the output of the parent firm, produce a similar product or assemble or adapt the parent firm's output for other countries does not affect the equity that the parent firm holds.

Once the results have stated that empirical analyses of the capital participation must take into consideration the sample selection (as raised by the econometric models), the results on the relevance of host country characteristic can be presented. Table 5 shows the results of the estimation of models which include the different sets of variables to capture differences across the countries in which the affiliates are located. Columns I and II show estimations of the models which try to capture by dummy variables the differences between the groups of countries previously described. The last two columns include variables measuring the political-legal framework (column III) and socio-cultural characteristics in each of them (column IV). 
Table 5. Estimation on the participation on foreign affiliates and different approaches on the destination country

\begin{tabular}{|c|c|c|c|c|c|c|c|c|c|}
\hline \multirow{2}{*}{\multicolumn{2}{|c|}{ Constant }} & I & & II & & III & & IV & \\
\hline & & $\begin{array}{c}330.600 \\
(3.210)\end{array}$ & $* *$ & $\begin{array}{c}290.800 \\
(2.856)\end{array}$ & $* *$ & $\begin{array}{c}302.700 \\
(2.553)\end{array}$ & $* *$ & $\begin{array}{c}348.100 \\
(3.131)\end{array}$ & $* *$ \\
\hline \multicolumn{2}{|c|}{ R. Mills } & $\begin{array}{r}-137.700 \\
(-2.570)\end{array}$ & ** & $\begin{array}{c}-120.900 \\
(-2.314)\end{array}$ & $* *$ & $\begin{array}{c}-114.000 \\
(-1.920)\end{array}$ & $*$ & $\begin{array}{c}-141.500 \\
(-2.476)\end{array}$ & $* *$ \\
\hline \multicolumn{2}{|c|}{ SIZE } & $\begin{array}{c}-65.570 \\
(2.047)\end{array}$ & $* *$ & $\begin{array}{c}-55.860 \\
(1.824)\end{array}$ & $*$ & $\begin{array}{c}-47.490 \\
(1.386)\end{array}$ & & $\begin{array}{c}-67.530 \\
(2.012)\end{array}$ & $* *$ \\
\hline \multicolumn{2}{|c|}{ SIZE $^{2}$} & $\begin{array}{c}4.635 \\
(-2.095)\end{array}$ & $* *$ & $\begin{array}{c}3.981 \\
(-1.886)\end{array}$ & $*$ & $\begin{array}{c}3.406 \\
(-1.439)\end{array}$ & & $\begin{array}{c}4.759 \\
(-2.057)\end{array}$ & $* *$ \\
\hline \multicolumn{2}{|c|}{$\mathrm{R} \& \mathrm{D}$} & $\begin{array}{c}-4.464 \\
(-2.326)\end{array}$ & $* *$ & $\begin{array}{c}-4.213 \\
(-2.284)\end{array}$ & $* *$ & $\begin{array}{c}-3.741 \\
(-1.813)\end{array}$ & * & $\begin{array}{c}-4.523 \\
(-2.279)\end{array}$ & $* *$ \\
\hline \multicolumn{2}{|c|}{ ADVER } & $\begin{array}{c}-5.142 \\
(-2.026)\end{array}$ & $* *$ & $\begin{array}{c}-4.422 \\
(-1.806)\end{array}$ & $*$ & $\begin{array}{c}-3.498 \\
(-1.162)\end{array}$ & & $\begin{array}{c}-5.139 \\
(-1.880)\end{array}$ & $*$ \\
\hline \multicolumn{2}{|c|}{ BRAND } & $\begin{array}{l}23.260 \\
(2.792)\end{array}$ & $* *$ & $\begin{array}{l}17.650 \\
(3.277)\end{array}$ & $* * *$ & $\begin{array}{l}10.410 \\
(1.832)\end{array}$ & $*$ & $\begin{array}{l}16.800 \\
(2.719)\end{array}$ & $* *$ \\
\hline \multicolumn{2}{|c|}{ AFFIL-SIZE } & $\begin{array}{c}0.707 \\
(0.165)\end{array}$ & & $\begin{array}{c}-0.795 \\
(-0.185)\end{array}$ & & $\begin{array}{c}-2.488 \\
(-0.249)\end{array}$ & & $\begin{array}{c}0.203 \\
(0.046)\end{array}$ & \\
\hline \multicolumn{2}{|c|}{ SIMIL } & $\begin{array}{c}5.345 \\
(-0.701)\end{array}$ & & $\begin{array}{c}-4.288 \\
(-0.612)\end{array}$ & & $\begin{array}{c}-3.375 \\
(-0.386)\end{array}$ & & $\begin{array}{c}-4.926 \\
(-0.651)\end{array}$ & \\
\hline \multicolumn{2}{|c|}{ TRADE } & $\begin{array}{c}3.172 \\
(0.416)\end{array}$ & & $\begin{array}{c}2.811 \\
(0.394)\end{array}$ & & $\begin{array}{c}1.690 \\
(0.198)\end{array}$ & & $\begin{array}{c}3.298 \\
(0.425)\end{array}$ & \\
\hline \multicolumn{2}{|c|}{ ADAPT } & $\begin{array}{c}7.274 \\
(1.218)\end{array}$ & & $\begin{array}{c}6.353 \\
(1.098)\end{array}$ & & $\begin{array}{c}2.796 \\
(0.350)\end{array}$ & & $\begin{array}{c}5.719 \\
(0.963)\end{array}$ & \\
\hline \multirow{5}{*}{ 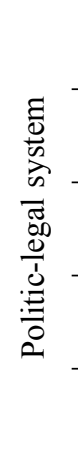 } & FRENCH & $\begin{array}{c}1.026 \\
(0.129)\end{array}$ & & & & & & & \\
\hline & GERMAN & $\begin{array}{c}2.605 \\
(0.215)\end{array}$ & & & & & & & \\
\hline & ANGLO-SAXON & $\begin{array}{c}1.460 \\
(0.183)\end{array}$ & & & & & & & \\
\hline & LATIN-AMERICAN & $\begin{array}{c}3.596 \\
(0.433)\end{array}$ & & & & & & & \\
\hline & ARAB & $\begin{array}{l}-49.210 \\
(-1.915)\end{array}$ & & & & & & & \\
\hline \multirow{3}{*}{ 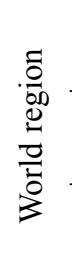 } & EU-15 & & & $\begin{array}{c}8.582 \\
(0.918)\end{array}$ & & & & & \\
\hline & OECD & & & $\begin{array}{l}16.700 \\
(1.724)\end{array}$ & & & & & \\
\hline & LATIN-AMERICAN & & & $\begin{array}{l}12.000 \\
(1.232)\end{array}$ & & & & & \\
\hline
\end{tabular}


End of Table 5

\begin{tabular}{|c|c|c|c|c|c|c|c|c|}
\hline & & I & & II & & III & IV & \\
\hline \multirow{5}{*}{ 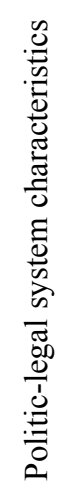 } & S-RIGHT & & & & & $\begin{array}{c}-2,167 \\
(-0,733)\end{array}$ & & \\
\hline & D-RIGHT & & & & & $\begin{array}{c}-0,803 \\
(-0,170)\end{array}$ & & \\
\hline & ACCOUNT & & & & & $\begin{array}{c}-0,111 \\
(-0,566)\end{array}$ & & \\
\hline & OWNERSHIP & & & & & $\begin{array}{c}-1,526 \\
(-0,153)\end{array}$ & & \\
\hline & POL-OPEN & & & & & $\begin{array}{c}3,481 \\
(0,181)\end{array}$ & & \\
\hline \multirow{4}{*}{ 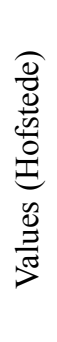 } & POWER & & & & & & $\begin{array}{c}-0,120 \\
(-0,515)\end{array}$ & \\
\hline & INDIVIDUAL & & & & & & $\begin{array}{c}-0,078 \\
(-0,530)\end{array}$ & \\
\hline & UNCERTAIN & & & & & & $\begin{array}{c}0,051 \\
(0,251)\end{array}$ & \\
\hline & MASCUL & & & & & & $\begin{array}{c}0,005 \\
(0,030)\end{array}$ & \\
\hline \multicolumn{2}{|c|}{ Number of observations } & 153 & & 153 & & 117 & 143 & \\
\hline \multicolumn{2}{|l|}{$\mathrm{R}^{2}$} & 0,223 & & 0,1894 & & 0,2022 & 0,1899 & \\
\hline \multicolumn{2}{|c|}{ Joint significance test } & 2,622 & $* *$ & 2,498 & ** & 1,707 & 2,144 & $* *$ \\
\hline
\end{tabular}

Notes: $t$-ratios in parentheses; $* * *$ and $* * *$ indicate statistical significance at 10,5 and $1 \%$ respectively.

As seen in Table 5, the last two models are estimated with a smaller sample, as some indexes are not available for some of the countries where Spanish manufacturers own affiliates. Among the lost cases, the most remarkable ones are Morocco, Eastern European countries (especially Poland and Ukraine) and China, because their political-legal system. In any case, the reduction in the sample size is small and results can be generalised.

From the results in Table 5 it can be inferred that Spanish firms do not seem to follow different participation strategies in their foreign affiliates on the basis on the country where the affiliate is located. Nor do cultural distance, as measured by Hofstede indexes (column IV), or political-legal framework (column III) have statistically significant coefficients. Additionally, the fact that dummy variables for groups of countries with similar characteristics do not have statistically significant estimated coefficients make more robust the conclusion that there are no different strategies for the participation degree once the decision to invest has been considered. It must be remembered that there is not a clearly theoretically based hypothesis on the effect of the difference between origin and destination countries (see Brouthers, K. D., Brouthers, L. E. 2001), and that the existing empirical evidence is also mixed (Tihanyi et al. 2005). The results of López- 
Duarte and Vidal-Suárez (2013) with a Spanish listed firms (that are larger and most concentrated in service activities than the sample used in this paper) show the relevance of sharing the language and the reinforcing effect of political risk.

\section{Conclusions}

This paper aims to highlight the importance of an adequate empirical approach to the study of capital participation in foreign affiliates. Specifically, it points out the need to consider that the subset of firms with affiliates abroad has some specific characteristics that must be considered in the econometric estimation of the participation in foreign affiliates. For the case under study (Spanish manufacturing firms), the analysis has concluded that considering the previous investment decision and the rank of values of the participation provides more accurate conclusions than the use of an empirical model that only considers whether it is a large or small participation. In any case, it must be said that this result can be expected from the conclusions suggested by econometric literature on this kind of data, and introducing these econometric models to the mode of entry literature can aid a better understanding of this topic.

The theoretical framework for the analysis has been widely used in the literature: Dunning's eclectic paradigm (for the decision to invest abroad) and Transaction Costs Economics (for the participation in subsidiaries). The results with this new approach indicate that the main explanatory variables on the existence of subsidiaries abroad are the size of the firms' advertising budgets, while the specific assets that R\&D generates seem to be negatively correlated. The fact that, as different studies have shown, R\&D activities push exports may explain these results if FDI and exports are considered as substitutes by Spanish manufacturers, although it can be explained by a technologyseeking strategy.

Concerning the equity structure, the results have shown a positive relationship with parent-firm size. This can be explained by the existence of some financial restrictions in Spanish firms that make it difficult to get the necessary resources to invest in foreign facilities. $R \& D$ has a negative relationship with participation of foreign affiliates, indicating that Spanish firms do not try to keep control of the technological resources they might transmit by means of greater participation. At the same time, the activities that the subsidiary firm develop abroad (trading the output of the parent firm, assembling or producing the similar output) do not show a significant coefficient.

The paper has paid special attention to host country characteristics as explanatory factors of the participation of the parent firm. Using different groupings of countries as well as indexes to measure the country distance through a multidimensional approach, the paper concludes that there are no important differences in affiliate participation depending on the country where the affiliate is located, once the other factors have been considered. This result suggests that Spanish manufacturing firms participate in their affiliates equity without being significantly affected by the country characteristics.

Given these results, some future lines of research can be considered. Firstly, the literature on the mode of entry issue should incorporate a wider framework where the explicit 
decision to become international is considered in order to evaluate how it affects mode of entry empirical analyses. Secondly, the paper has only considered a first-stage decision on owning or not owning a subsidiary abroad; a richer approach could consider alternative modes of internationalisation that do not require equity participation (such as licences or exports). Thirdly, future results from other countries will have a reference for comparison other than the classical ones, since the Spanish case presents some differences from the results found in other countries, on which most of the empirical literature has been concentrated. It is worth noting that Spanish multinationals are a recent phenomenon and are concentrated in countries where the cultural distance is low, etc. Fourthly, the proposed use of different measures to capture the differences between home and host countries may highlight some factors that otherwise could remain hidden.

\section{References}

Ahsan, M.; Musteen, M. 2011. Multinational enterprises' entry mode strategies and uncertainty: a review and extension, International Journal of Management Reviews 13: 376-392.

http://dx.doi.org/10.1111/j.1468-2370.2010.00296.x

Akande, W. A.; Adetoun, B. E.; Tserere, M. M.; Adewuyi, M. F.; Akande, E. T. 2008. Should we put locals in charge? Managing relationships within prospective US - South African joint ventures, Journal of Business Economics and Management 11: 550-575.

http://dx.doi.org/10.3846/jbem.2010.27

Anand, J.; Delios, A. 1997. Location specificity and the transferability of downstream assets to foreign subsidiaries, Journal of International Business Studies 28(3): 579-603.

http://dx.doi.org/10.1057/palgrave.jibs.8490112

Anderson, E.; Gatignon, H. 1986. Modes of foreign entry: a transaction cost analysis and propositions, Journal of International Business Studies 17(3): 1-26.

http://dx.doi.org/10.1057/palgrave.jibs.8490432

Beck, T.; Demirgüç-Kunt, A.; Levine, R. 2001. Law, politics and finance, World Bank Policy Research Working Paper 2585. Washington D.C.

Birkinshaw, J.; Hood, N. 2000. Characteristics of foreign subsidiaries in industry clusters, Journal of International Business Studies 32: 141-154. http://dx.doi.org/10.1057/palgrave.jibs.8490893

Bowe, M.; Golesorkhi, S; Yamin, M. 2013. Explaining equity shares in international joint ventures: combining the influence of asset characteristics, culture and institutional differences, $R e$ search in International Business and Finance. http://dx.doi.org/10.1016/j.ribaf.2013.06.008

Brouthers, K. D.; Brouthers, L. E. 2001. Explaining the national cultural distance paradox, Journal of International Business Studies 32: 177-189. http://dx.doi.org/10.1057/palgrave.jibs.8490944

Brouthers, K. D.; Hennart, J.-F. 2007. Boundaries of the firm: insights from international entry mode research, Journal of Management 33: 395-425 http://dx.doi.org/10.1177/0149206307300817

Brouthers, K. D.; Brouthers, L. E.; Werners, S. 2003. Transaction cost-enhanced entry mode choices and firm performance, Strategic Management Journal 24: 1239-1248.

http://dx.doi.org/10.1002/smj.362

Canabal, A.; White, G. O. 2008. Entry mode research. Past and future, International Business Review 17: 267-284. http://dx.doi.org/10.1016/j.ibusrev.2008.01.003

Chang, S.-J.; Chung, J.; Moon, J. 2013. When do wholly owned subsidiaries perform better than joint ventures?, Strategic Management Journal 34: 317-337. http://dx.doi.org/ 10.1002/smj.2016

Delgado-Gómez, J. M.; Ramírez-Alesón, M.; Espitia-Escuer, M. A. 2004. Intangible resources as a key factor in the internationalisation of Spanish firms, Journal of Economic Behavior \& 
Organization 53: 477-494. http://dx.doi.org/10.1016/j.jebo.2002.11.001

Demirbag, M.; Tatoglu, E.; Glaister, K.W. 2009. Equity-based entry modes of emerging country multinationals: Lessons from Turkey, Journal of World Business 44: 445-462.

http://dx.doi.org/10.1016/j.jwb.2008.11.009

Dimelis, S.; Louri, H. 2002. Foreign ownership and production efficiency: a quantile regression analysis, Oxford Economic Papers 54: 449-469. http://dx.doi.org/10.1093/oep/54.3.449

Dow, D.; Karunaratna, A. 2006. Developing a multidimensional instrument to measure psychic distance stimuli, Journal of International Business Studies 37(5): 578-602.

Dunning, J. E. 1979. Explaining changing patterns of international production: in defence of the eclectic theory, Oxford Bulletin of Economics and Statistics 41(4): 269-295.

http://dx.doi.org/10.1111/j.1468-0084.1979.mp41004003.x

Erramilli, M. K. 1996. National and subsidiary ownership patterns in multinational corporations, Journal of International Business Studies 27(2): 225-248.

http://dx.doi.org/10.1057/palgrave.jibs.8490133

Fazzari, S. M.; Hubbard, G.; Petersen, B. 1988. Financing constraints and corporate investment, Brookings Papers on Economic Activity 1: 141-195. http://dx.doi.org/10.2307/2534426

Galán, J. I.; González-Benito, J. 2006. Distinctive determinant factors of Spanish foreign direct investment in Latin America, Journal of World Business 41: 171-189.

Gatignon, H.; Anderson, E. 1988. The multinational corporation degree of control over subsidiaries: an empirical test of a transaction cost explanation, Journal of Law, Economics and Organization 4: 305-336.

Gupta, V.; Hanges, P. J.; Dorfman, P. 2002. Cultural clusters: methodology and findings, Journal of World Business 37: 11-15. http://dx.doi.org/10.1016/S1090-9516(01)00070-0

Hennart, J.-F.; Zeng, M. 2002. Cross-cultural differences and joint venture longevity, Journal of International Business Studies 33(4): 699-716. http://dx.doi.org/10.1057/palgrave.jibs.8491040

Hofstede, G. H. 1991. Cultures and Organizations. Software of the Mind. London: McGraw-Hill.

Javorcik, B. S. 2004. Does foreign direct investment increase the productivity of domestic firms? In search of spillovers through backward linkages, The American Economic Review 94(3): 605627. http://dx.doi.org/10.1257/0002828041464605

Javorcik, B. S.; Spatereanu, M. 2008. To share or not to share: does local participation matter for spillovers from foreign direct investment, Journal of Development Economics 85: 194-217. http://dx.doi.org/10.1016/j.jdeveco.2006.08.005

Jiang, M. S.; Chu, R.; Pan, Y. 2011. Anticipated duration of international joint ventures: a transaction cost perspective, Journal of International Management 17: 175-183.

http://dx.doi.org/10.1016/j.intman.2011.01.001

Le Bas, C.; Sierra. C. 2002. 'Location versus home country advantages' in R\&D activities: some further results on multinationals' locational strategies, Research Policy 31: 589-609.

http://dx.doi.org/10.1016/S0048-7333(01)00128-7

Knickerbocker, F. T. 1973. Oligopolistic Reaction and the Multinational Enterprise. Cambridge, MA: Harvard University Press.

Kogut, B.; Singh, H. 1988. The effect of national culture on the choice of entry mode, Journal of International Business Studies 19(3): 411-432. http://dx.doi.org/10.1057/palgrave.jibs.8490394

LaPorta, R.; Shleifer, A.; Vishny, R. W. 1998. Law and finance, Journal of Political Economy 106: 1113-1155. http://dx.doi.org/10.1086/250042

López-Duarte, C.; Vidal-Suárez, M. M. 2013. Cultural distance and the choice between wholly owned subsidiaries and joint ventures, Journal of Business Research 66: 2252-2261.

http://dx.doi.org/10.1016/j.jbusres.2012.02.017 
Maddala, G. S. 1983. Limited-dependent and Qualitative Variables in Econometrics. Cambridge: Cambridge University Press.

Merino, F.; Salas, V. 2002. Causes and consequences of export channel integration, Spanish Economic Review 4: 239-259. http://dx.doi.org/10.1007/s101080200056

Miozzo, M.; Yamin, M.; Ghauri, P. N. 2012. Strategy and structure of service multinationals and their impact on linkages with local firms, The Service Industries Journal 32: 1171-1191.

http://dx.doi.org/10.1080/02642069.2012.662492

Morschett, D.; Schramm-Klein, H.; Swoboda, B. 2011. Decades of research on market entry modes: what do we really know about external antecedents of entry mode choice?, Journal of International Management 16: 60-77. http://dx.doi.org/10.1016/j.intman.2009.09.002

Mutinelli, M.; Piscitello, L. 1998. The entry mode choice of MNEs: an evolutionary approach, Research Policy 27: 491-506. http://dx.doi.org/10.1016/S0048-7333(98)00063-8

Nakamura, M.; Yeung, B. 1994. On the determinants of foreign ownership shares: evidence from US firms' joint ventures in Japan, Managerial and Decision Economics 15: 95-106.

http://dx.doi.org/10.1002/mde.4090150202

Nakamura, N.; Xie, J. 1998. Nonverifiability, noncontractaibility and ownership determination models in foreign direct investment, with an application to foreign operations in Japan, International Journal of Industrial Organization 16: 57-599.

http://dx.doi.org/10.1016/S0167-7187(97)00019-2

Park, B I.; Oh, K.-S.; Choi, S. B. 2012. Acquisition of local market information in international joint ventures: service sectors, The Service Industries Journal 32: 1077-1096.

http://dx.doi.org/10.1080/02642069.2012.662491

Prashantham, S.; Birkinshaw, J. 2008. Dancing with gorillas: how small companies can partner effectively with multinational corporations, California Management Review 51: 6-23.

Rasheed, H. S. 2005. Foreign entry mode and performance: the moderating effects of environment, Journal of Small Business Management 43: 41-54.

http://dx.doi.org/ 10.1111/j.1540-627X.2004.00124.x

Sanna-Randaccio, F. 1991. Ownership patterns of Italian joint ventures abroad: country, industry and firm-specific determinants, CIDEI Working Paper 10.

Schindler, D.; Schjelderup, G. 2012. Debt shifting and ownership structure, European Economic Review 56: 635-647. http://dx.doi.org/10.1016/j.euroecorev.2012.02.015

Shenkar, O. 2001. Cultural distance revisited: towards a more rigorous conceptualization and measurement of cultural differences, Journal of International Business Studies 32: 519-535. http://dx.doi.org/10.1057/palgrave.jibs.8490982

Siripaisalpipat, P.; Hoshino, Y. 2000. Firm-specific advantages, entry modes and performance of Japanese FDI in Thailand, Japan and the World Economy 12: 33-48.

Teece, D. J. 1986. Transactions cost economics and the multinational enterprise: an assessment, Journal of Economic Behavior and Organization 7(1): 21-46.

http://dx.doi.org/10.1016/0167-2681(86)90020-X

Tihany, L.; Griffith, D. A.; Russell, C. J. 2005. The effect of cultural distance on entry mode choice, international diversification, and MNE performance: a meta-analysis, Journal of International Business Studies 36(3): 270-283. http://dx.doi.org/10.1057/palgrave.jibs.8400136

Williamson, O. E. 1975. Markets and Hierarchies: Analysis and Antitrust Implications. New York: Ed. The Free Press.

Williamson, O. E. 1985. The Economic Institutions of Capitalism. New York: Ed. The Free Press. Williamson, O. E. 1991. Strategizing, economizing, and economic organization, Strategic Management Journal 12: 72-94. http://dx.doi.org/10.1002/smj.4250121007 
Yamin, M.; Golesorkhi, S. 2010. Cultural distance and the pattern of equity ownership structure in international joint ventures, International Business Review 19: 457-467.

http://dx.doi.org/10.1016/j.ibusrev.2009.11.004

Zhao, H.; Luo, Y.; Suh, T. 2004. Transaction cost determinants and ownership-based entry mode choice: a meta-analytical review, Journal of International Business Studies 35: 524-544.

http://dx.doi.org/10.1057/palgrave.jibs.8400106

\section{APPENDIXES}

\section{A) Country grouping in regions}

$1^{\text {st }}$ grouping

\begin{tabular}{ll}
\hline \multicolumn{1}{c}{ Groups: } & \multicolumn{1}{c}{ Formed by: } \\
\hline \multirow{2}{*}{ European Union } & $\begin{array}{l}\text { Austria, Belgium, Denmark, Finland, France, Germany, Greece, Holland, } \\
\text { Ireland, Italy, Luxemburg, Portugal, Sweden, United Kingdom }\end{array}$ \\
\hline OECD* & $\begin{array}{l}\text { Canada, Czech Republic, Hungary, Iceland, Japan, Korea, New Zealand, } \\
\text { Norway, Poland, Slovakia, Sweden, Turkey, United States }\end{array}$ \\
\hline Latin-America & Whole Latin-America, but Cuba and Puerto Rico \\
\hline Others & Rest of the World \\
\hline
\end{tabular}

Notes: * Although Mexico joined OECD in 1994, it has been included in Latin-America given that there are more similarities with those countries than with the ones in the OECD group.

Spain fits in the European Union group, so this is supposed to be the closest group to the reference situation.

$2^{\text {nd }}$ grouping

\begin{tabular}{ll}
\hline \multicolumn{1}{c}{ Groups: } & \multicolumn{1}{c}{ Formed by*: } \\
\hline French tradition & France, Belgium, Portugal, Italy \\
\hline Anglo-Saxon tradition & United Kingdom, Ireland, United States \\
\hline Germanic tradition & Germany, Austria, Switzerland, Holland \\
\hline Arab tradition & Morocco, Tunisia, Turkey \\
\hline Latin-American & Whole Latin-America, but Cuba and Puerto Rico \\
\hline Other & East Europe, China, Philippines, Cuba \\
\hline
\end{tabular}

Notes: * that although some more countries could be included in each of the first five groups, the fact that none of the affiliated firms in the study are located there makes irrelevant the inclusion of the country in any of the groups.

Spain fits in the French tradition group, so this is supposed to be the closest group to the reference situation. 


\section{B) Indexes to classify countries}

Political-Legal frame

\begin{tabular}{ll}
\hline \multicolumn{1}{c}{ Index } & \multicolumn{1}{c}{ Source } \\
\hline Shareholders rights protection & LaPorta, Shleifer and Vishny (1998) \\
\hline Creditors protection & LaPorta (1998) \\
\hline Accountancy systems reliability & $\begin{array}{l}\text { Center for International Financial Analisis, published } \\
\text { in LaPorta, Shleifer and Vishny (1998) }\end{array}$ \\
\hline Political openness & Beck, Demirgüç-Kunt and Levine (2001) \\
\hline \multicolumn{1}{c}{ Cultural distance } \\
\hline Power distance & $\begin{array}{l}\text { It focuses on the degree of equality, or inequality, between people in the } \\
\text { country's society. }\end{array}$ \\
\hline $\begin{array}{l}\text { Individualism } \\
\text { It focuses on the degree the society reinforces individual or collective } \\
\text { achievement and interpersonal relationships. }\end{array}$ \\
$\begin{array}{ll}\text { Uncertainty } \\
\text { avoidance }\end{array}$ & $\begin{array}{l}\text { It focuses on the level of tolerance for uncertainty and ambiguity within the } \\
\text { society - i.e. unstructured situations. }\end{array}$ \\
\hline $\begin{array}{l}\text { Masculine } \\
\text { values }\end{array}$ & $\begin{array}{l}\text { It focuses on the degree the society reinforces, or does not reinforce, the } \\
\text { traditional masculine work role model of male achievement, control, and } \\
\text { power. }\end{array}$ \\
\hline
\end{tabular}

Published in: Hofstede (1991) and http://www.geert-hofstede.com

Fernando MERINO obtained his PhD in Economics at the University of Alcalá in 2001 and is currently Associate Professor of Applied Economics at Universidad de Murcia. His research fields include firms' internationalisation and outsourcing. He has published papers in international journals such as Strategic Management Journal, Industrial and Corporate Change and Services Industries Journal and Spanish journals such as Revista de Economía Aplicada and Papeles de Economía Aplicada, among others. He has served as a referee for a number of national and international journals, as well as Spanish funding agencies. More details can be seen at his personal homepage, http://www.um.es/ docencia/fmerino. 